\title{
Species diversity variations in Neogene deep-sea benthic foraminifera at ODP Hole 730A, western Arabian Sea
}

\author{
Yuvaraja Arumugm ${ }^{1, *}$, Anil K Gupta ${ }^{1,2}$ and Mruganka K Panigrahi ${ }^{1}$ \\ ${ }^{1}$ Indian Institute of Technology, Kharagpur 721 302, India. \\ ${ }^{2}$ Wadia Institute of Himalayan Geology, Dehradun 248 001, India. \\ ${ }^{*}$ Corresponding author. e-mail: agl.yuva@gmail.com
}

Deep-sea benthic foraminifera are an important and widely used marine proxy to understand paleoceanographic and paleoclimatic changes on regional and global scales, owing to their sensitivity to oceanic and climatic turnovers. Some species of benthic foraminifera are sensitive to changes in water mass properties whereas others are sensitive to organic fluxes and deep-sea oxygenation. Benthic faunal diversity has been found closely linked to food web, bottom water oxygen levels, and substrate and water mass stability. The present study is aimed at analyzing species diversity trends in benthic foraminifera and their linkages with Indian monsoon variability during the Neogene. Species diversity of benthic foraminifera is examined in terms of number of species (S), information function (H), equitability (E) and Sanders' rarefied values, which were combined with relative abundances of high and low productivity benthic foraminifera at Ocean Drilling Program Hole 730A, Oman margin, western Arabian Sea. The Oman margin offers the best opportunity to understand monsoon-driven changes in benthic diversity since summer monsoon winds have greater impact on the study area. The species diversity was higher during the early Miocene Climatic Optimum ( 17.2-16.4 Ma) followed by a decrease during 16.4-13 Ma coinciding with a major increase in Antarctic ice volume and increased formation of Antarctic Bottom Water. All the diversity parameters show an increase during 13-11.6 Ma, a gradual decrease during 11.6-9 Ma and then an increase with a maximum at $7 \mathrm{Ma}$. Thereafter the values show little change until $1.2 \mathrm{Ma}$ when all the parameters abruptly decrease. The benthic foraminiferal populations and diversity at Hole $730 \mathrm{~A}$ were mainly driven by the Indian monsoon, and polar waters might have played a minor or no role since early Neogene period as the Arabian Sea is an enclosed basin.

\section{Introduction}

Paleoclimate studies provide useful information for understanding land-ocean-atmospheric interactions over different time scales. The present day climatic regimes resulted from changes in polar ice volume including waning and waxing of polar ice sheets since the late Oligocene (Kennett and Barker 1990; Zachos et al. 2001). The plate tectonic evolution of the Indian subcontinent (e.g., uplift of the Himalaya-Tibetan plateau complex) and opening and closing of the seaways (e.g., opening of the Drake Passage and closing of the Panamanian, Tethyan, and Indonesian seaways) also had significant impact on the global climate system (Kennett et al. 1974; Molnar et al. 1993; Haug and Tiedemann 1998; Lawver and Gahagan 1998; Barker and Thomas 2004; Hamon et al. 2013). The major expansion of the East Antarctic Ice Sheet (EAIS) began in the earliest Oligocene which was permanently established in the middle Miocene (Kennett and Barker 1990; Zachos et al. 2001). The

Keywords. Benthic foraminifera; Arabian Sea; species diversity; productivity; Indian monsoon; upwelling. 
increased Antarctic ice volume during this time intensified thermal gradients between the tropics and the poles that increased the seasonality of surface ocean productivity and deep water oxygenation in all the ocean basins (Kennett and Barker 1990; Ehrmann and Mackensen 1992; Zachos et al. 2001; Barker and Thomas 2004; Gupta et al. 2004). The increase in Antarctic ice volume in the middle Miocene intensified the production and circulation of the Antarctic Bottom Water (AABW) (Kennett and Barker 1990). These changes in ocean surface productivity, deep-sea circulation, and oxygenation brought pronounced changes in marine fauna in the Indian Ocean (Gupta et al. 2004).

The continuous build-up of Antarctic ice sheets strengthened the wind regimes which drove openocean and coastal upwelling over large parts of the Indian, Pacific and Atlantic oceans during the middle to late Miocene (Gupta et al. 2004). This upwelling-driven productivity led to the formation of a 'biogenic bloom' and expansion of the oxygen minimum zone (OMZ) at intermediate water depths within both the Indian and Pacific oceans during the middle to late Miocene ( $15-5 \mathrm{Ma})$ (Pisias et al. 1995; Dickens and Owen 1999; Gupta and Thomas 1999; Hermoyian and Owen 2001). As a result, the deep-sea benthic foraminiferal faunas underwent restructuring and changes in diversity worldwide (e.g., Douglas and Woodruff 1981; Gupta et al. 2001, 2013; Singh et al. 2012). In the western Arabian Sea, distribution of deepsea benthic foraminifera, biomass, and diversity differ from other parts of the Indian and other ocean basins since the area is landlocked and is located under the influence of the monsoon regime (Hermelin and Shimmield 1990; Gupta 1994; Kurbjeweit et al. 2000). Recently, several researchers analyzed changes in water mass circulation, surface productivity, and response of deep-sea biota to these changes in the Arabian Sea during the Neogene (e.g., Boersma and Mikkelsen 1990; Hermelin and Shimmield 1990; Kroon et al. 1991; Prell et al. 1992; Gupta and Thomas 1999, 2003; Kawagata et al. 2006; Smart et al. 2007). The variations in deep-sea benthic foraminiferal diversity have been related to the presence of food, heterogeneity of the habitat, deep-ocean circulation, and predation (Buzas and Gibson 1969; Gibson and Buzas 1973; Gooday 1988; Rai and Singh 2001; Singh et al. 2012; Gupta et al. 2013).

In this study, we examined species diversity trends in late Neogene deep-sea benthic foraminifera at Ocean Drilling Program (ODP) Hole 730A in the western Arabian Sea in order to understand the influence of monsoon driven changes in deep water oxygenation and surface productivity on benthic faunal diversity during the Neogene. An attempt was also made to discriminate between monsoon driven changes and those induced by pole-induced deep-sea circulation on species diversity.

\section{Study area}

ODP Hole $730 \mathrm{~A}$ is located off the continental margin of Oman, western Arabian Sea (water depth $-1065.8 \mathrm{~m}$; latitude $7^{\circ} 43.885^{\prime} \mathrm{N}$; longitude $57^{\circ} 41.519^{\prime} \mathrm{E}$; figure 1 ) which, in recent years, has attracted numerous excellent studies to reconstruct Indian monsoon driven deep and surface paleoceanographic changes in the northern Indian Ocean during different time periods. Intense southwest (SW) monsoon winds drive strong upwelling off the coast of Oman, causing enhanced surface biological production and activity during the summer (June-September) season (Wyrtki 1971; Brock et al. 1991; Schott and McCreary 2001). On the contrary, during the winter or northeast (NE) monsoon season (November-February), the prevalence of dry and weak northeasterly winds promotes oligotrophic conditions in the Arabian Sea (e.g., Schott and McCreary 2001). Upwelling processes allow deeper-cold-nutrient rich water to shoal and maintain high levels of euphotic activity in the Arabian Sea (Hermelin and Shimmield 1990). This results in a pronounced oxygen minimum zone with oxygen levels below $0.05 \mathrm{ml} / \mathrm{l}$ at intermediate water depths between 200 and $1200 \mathrm{~m}$ throughout the Arabian Sea (Hermelin and Shimmield 1990). The OMZ controls microbial decay, respiration by biota, and increased preservation of monsoon-driven organic matter and seasonal fluxes to the deep sea sediments (Hermelin and Shimmield 1990; Gupta 1994; Reid 2003).

The Red Sea and Persian Gulf outflows feed a high-salinity, low-oxygen, and nutrient-rich warm water mass (Red Sea-Persian Gulf Intermediate Water or RSPGIW) to intermediate water depths of the northwestern Arabian Sea. It is a major constituent of intermediate water in the Arabian Sea which mixes down at 1000-2000 m water depths (Gupta and Srinivasan 1992; You 1998; Kawagata et al. 2006). The intensity of RSPGIW and sinking of Arabian Sea surface water is controlled by NE monsoon winds over the Arabian Sea (Woelk and Quadfasel 1996). Below RSPGIW, lies the North Indian Deep Water (NIDW) at 1500-4000 m water depths (Wyrtki 1973; Tomczak and Godfrey 1994). In the northwestern Indian Ocean, NIDW has high salinity $(35.85 \mathrm{psu})$ with a temperature of $2^{\circ} \mathrm{C}$ and oxygen of $4.7 \mathrm{ml} / \mathrm{l}$, which is formed by the mixing of saline North Atlantic Deep Water (NADW) (Vincent et al. 1974), Antarctic Intermediate Water (AAIW) and well-oxygenated AABW, as well as RSPGIW to the north of the $10^{\circ} \mathrm{S}$ 


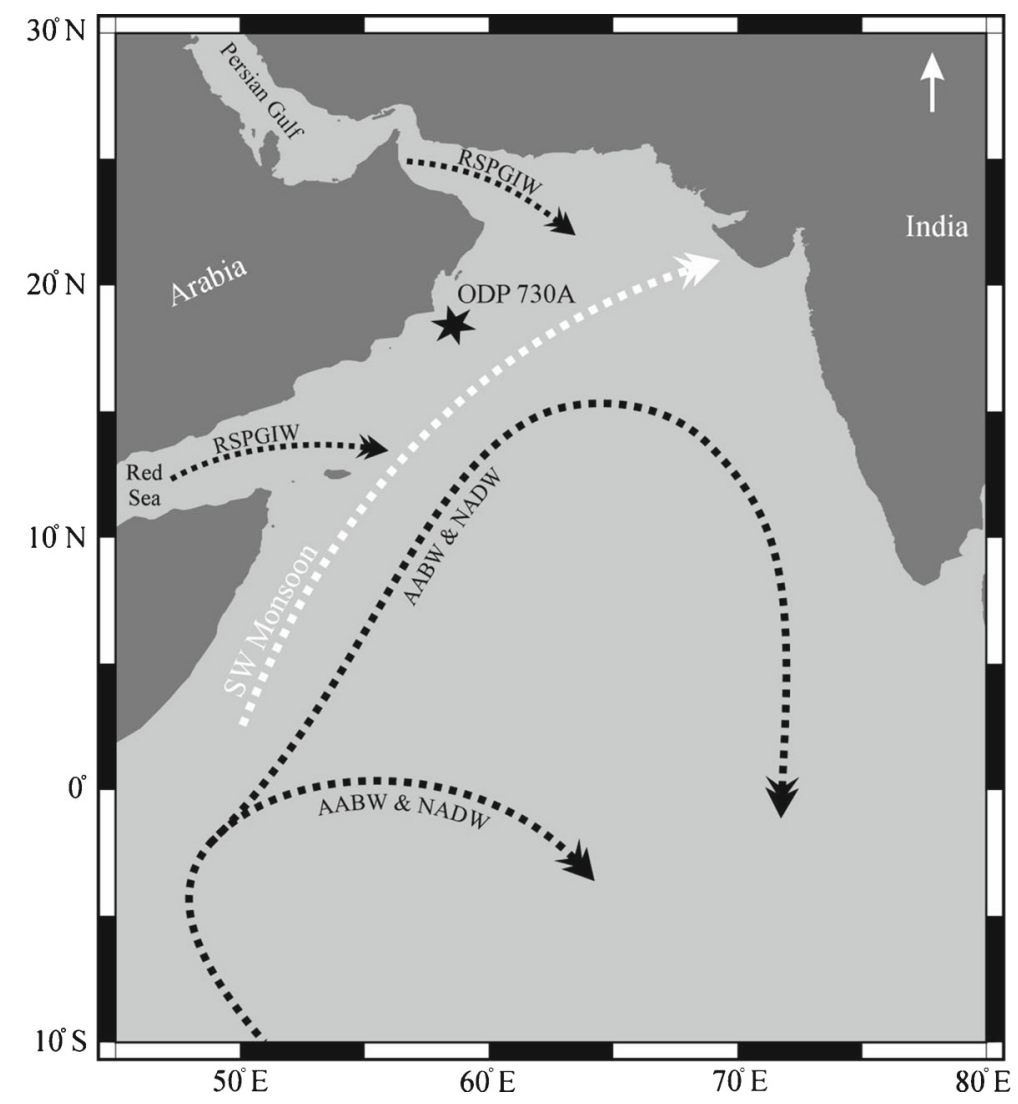

Figure 1. Location map of ODP Hole 730A, Oman margin, western Arabian Sea. Also shown are present day intermediate and bottom water flows (Kawagata et al. 2006) and direction of the southwest monsoon current (Findlater 1971). $(\mathrm{AABW}=$ Antarctic Bottom Water; NADW=North Atlantic Deep Water; RSPGIW=Red Sea-Persian Gulf Intermediate Water).

Hydrochemical Front (Wyrtki 1971; Tchernia 1980). Wyrtki (1988) and Reid (2003) referred to this water mass as Lower Circumpolar Deep Water (LCDW), which is a carbonate undersaturated, oxygen-rich water mass flowing as a western boundary current from the southern Indian Ocean towards the north through the western Indian basins at $>3800 \mathrm{~m}$ water depths.

\section{Materials and methods}

We examined 200 core samples of 10 cc volume from ODP Hole 730A covering a sediment thickness of $403 \mathrm{~m}$ below sea floor (mbsf), which were processed using the standard procedures as described in Gupta and Thomas (1999). The average age per sample is $\sim 85,000$ years based on planktic foraminiferal and calcareous nannofossil datums (Prell et al. 1989), which were updated to Berggren et al. (1995). Sample processing was carried out in the Paleoceanography and Paleoclimatology Laboratory, Department of Geology \& Geophysics, IIT, Kharagpur. Each sample was soaked in water with a few drops of diluted Hydrogen Peroxide $\left[\mathrm{H}_{2} \mathrm{O}_{2}(15 \%)\right]$ and half a spoon of baking soda for approximately 8-10 hours. The soaked samples were washed over a $63 \mu \mathrm{m}$ size sieve using a jet of clean tap water, dried in an electric oven at $\sim 50^{\circ} \mathrm{C}$, and dry samples were transferred to labelled glass vials. After each wash the sieve was stained with methylene blue to identify contaminated specimens from the previous sample.

Each sample was dry-sieved over $125 \mu \mathrm{m}$ size sieve and split into suitable aliquots to obtain $\sim 300$ individuals of benthic foraminifera under the microscopic. Each sample was thinly scattered on a black picking tray ruled with gridlines under the microscope. The specimens were identified and counted to calculate percentages. The greater than $125 \mu \mathrm{m}$ size fraction was studied under the microscope for better comparison with the recent studies on benthic foraminifera from other ocean basins.

We have plotted percentages of most dominant and environmentally sensitive benthic foraminiferal species including Uvigerina proboscidea, Epistominella exigua, Cibicides wuellerstorfi, Nuttallides umbonifera and OMZ taxa (comprising Bolivina seminuda, Bulimina aculeata, Bulimina exilis, Chilostomella ovoidea, and Uvigerina peregrina) (Sen Gupta and Bernhard 1999) with diversity parameters and global oxygen and carbon isotope 
curves (Zachos et al. 2001). The numerical ages are based on foraminiferal and nannofossil datums (Prell et al. 1989) and updated to the age model of Berggren et al. (1995). Species diversity was studied in terms of SHE analysis, where $S$ represents the number of species, $H$ is the information function and $E$ is the equitability. The information function $(H)$ was calculated using the ShannonWiener diversity index (Shannon and Wiener 1949) given by the formula

$$
H=-\sum_{i=1}^{S} p_{i} \ln p_{i}
$$

where $S$ is the number of species in a given sample, $p_{i}$ is the proportion of the $i$ th species in the sample and $\mathrm{ln}$ is the natural logarithm. To calculate the equitability, the mathematical expression given by Buzas and Gibson (1969) was used:

$$
E=e^{H} / S \text {. }
$$

Sanders' rarefaction number was also calculated for each sample by rarefying against 100 individuals (Sanders 1968). Sanders' values are commonly used in the ecological studies of deep-sea fauna (e.g., Rex et al. 1997).

The combined plots of species diversity and high seasonality species Epistominella exigua and Cibicides wuellerstorfi, OMZ species and dissolution resistant species Nuttallides umbonifera are shown in figure 2 to understand influence of monsoon seasonality and deep-sea circulation on benthic fauna (figure 2). To strengthen our understanding of species diversity and monsoon relationships, we also correlated Sanders' values with productivity indicator taxon Uvigerina proboscidea during selected time intervals using linear correlation method (figure 4).

Uvigerina proboscidea flourishes in high productivity zones of the Indian Ocean irrespective of oxygen content of deep waters (Gupta and Srinivasan 1992; Gupta and Thomas 1999; Almogi-Labin et al. 2000; Singh and Gupta 2004). High relative abundances of Uvigerina proboscidea indicate a year-round, sustained and high flux of organic matter from the sea surface to the ocean floor during intervals of high surface productivity (Gupta and Srinivasan 1992; Gupta and Thomas 1999; De and Gupta 2010). Gupta and Srinivasan (1992) observed a relationship between higher abundances of Uvigerina proboscidea and increased upwelling due to intensification of trade winds in the open eastern Indian Ocean.

Epistominella exigua is a cosmopolitan species which feeds opportunistically on phytodetritus deposited seasonally on the sea floor and linked with elevated oxygen level (Gooday 1993;
Smart et al. 1994; Schmiedl et al. 1997; Jannink et al. 1998; Kurbjeweit et al. 2000). This species has been used as a proxy for pulsed organic inputs to the sea floor and relative changes in productivity (Smart et al. 1994; Saraswat et al. 2005). Cibicides wuellerstrofi has been suggested as an epibenthic foraminifer that prefers to live on raised objects above the sediment-water interface in high energy environments (Lutze and Thiel 1989; Linke and Lutze 1993; Mackensen et al. 1995). This species is a suspension feeder occurring in regions of low food supply and low organic carbon flux (Linke and Lutze 1993). The numerical dominance of $C$. wuellerstrofi in the Arctic Basin and the Norwegian-Greenland Sea has been inferred to reflect scarcity of food particles in the sediment (Lutze and Thiel 1989; Linke and Lutze 1993). On the Ontong Java Plateau this species occurs abundantly in post-glacial environments typified by low productivity (Burke et al. 1993). Cibicides wuellerstrofi is associated with AABW (Corliss 1979, 1983). Nuttallides umbonifera, though found in several habitats, has mostly been found associated with corrosive bottom waters in the Atlantic Ocean (Bremer and Lohmann 1982). This species has been defined as an opportunist (Corliss 1983; De and Gupta 2010).

Bolivina seminuda is a shallow infaunal species, which has been recorded in high abundance within the central part of the OMZ. This species has better adaption to live in disoxic environments (Glock et al. 2011). The abundances of Bulimina exilis are found in the fine fraction $(63-150 \mathrm{~mm})$ of samples from the OMZ at the end of the summer in Pakistan Margin (Jannink et al. 1998). Bulimina aculeata, an intermediate to deep infaunal species, has been reported at lower bathyal depths and below lower boundary of OMZ in the Arabian Sea (Hermelin and Shimmield 1990; Miao and Thunell 1993; Jannink et al. 1998). This species dominates high-productivity, interglacial intervals in the Arabian Sea (Almogi-Labin et al. 2000). The deep infaunal Chilostomella ovoidea has found in OMZ with assemblage of Uvigerina peregrina in the northwestern Arabian Sea. This species has a close relationship with the oxygen content of the overlying water masses (Hermelin and Shimmield 1990). All these low oxygen tolerant species have been reported in OMZ environment from different oceans (Sen Gupta and Bernhard 1999).

\section{Results and discussion}

Deep-sea benthic foraminifera capture signatures of export flux to the deep sea resulting from monsoon-induced changes in the surface and deepwater column of the Arabian Sea (Hermelin 1992; 


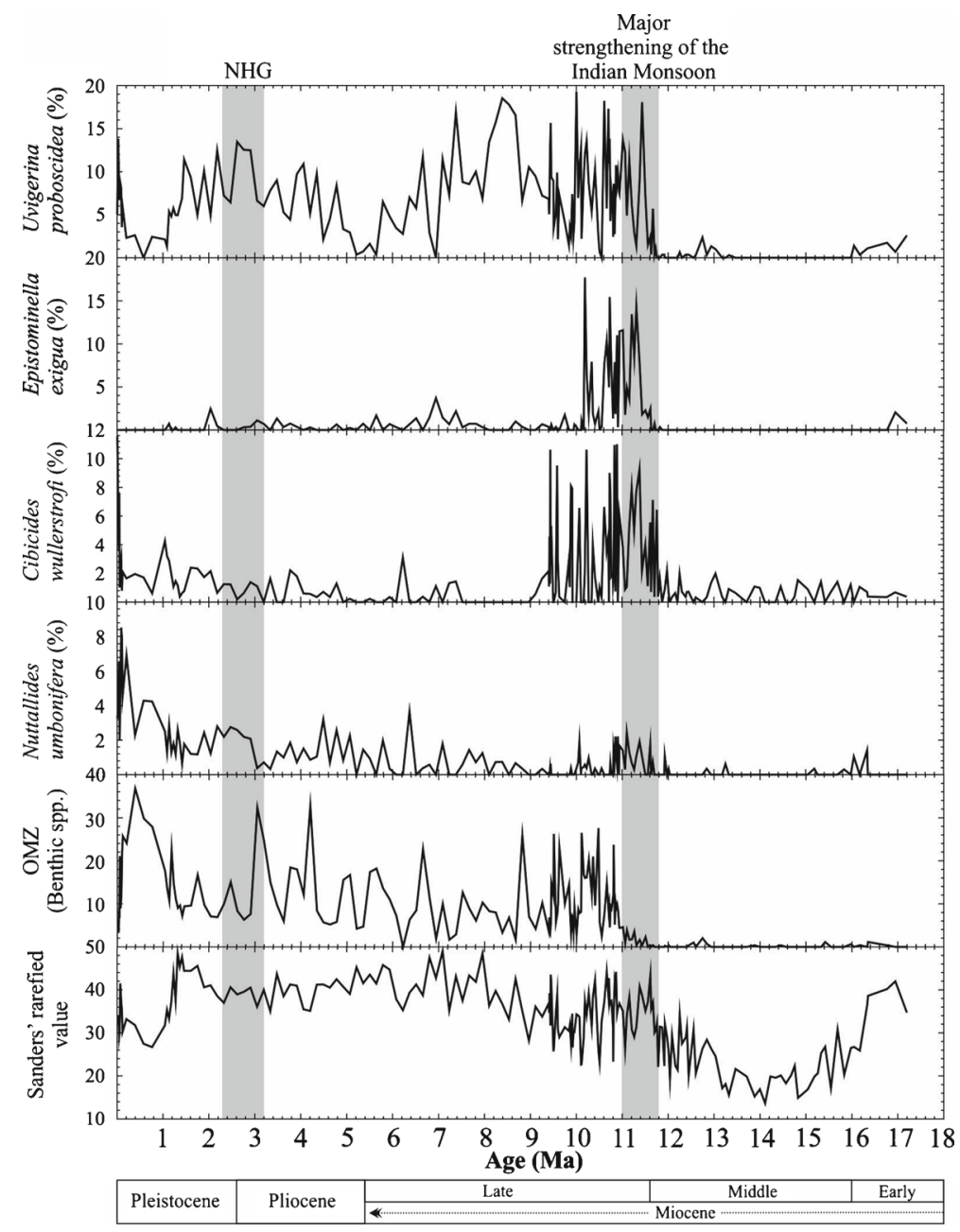

Figure 2. Relative abundances of benthic foraminiferal species Epistominella exigua, Cibicides wuellerstorfi, Nuttallides umbonifera and OMZ taxa (comprising Bolivina seminuda, Bulimina aculeata, Bulimina exilis, Chilostomella ovoidea and Uvigerina peregrina) combined with Sanders' rarefied values and Uvigerina proboscidea percentages.

Gupta and Thomas 1999). The Arabian Sea has more distinct deep-sea benthic foraminiferal regimes as compared to the southeastern Indian Ocean because of the latter's configuration and presence of a pronounced OMZ at depths ranging from $\sim 200$ to $1200 \mathrm{~m}$ which is caused by high organic flux from monsoon-induced high surface productivity and increased oxygen consumption by the deep-sea biota (Hermelin and Shimmield 1990; Den Dulk et al. 2000; Mazumder et al. 2003; Nigam et al. 2007; De and Gupta 2010).

At Hole $730 \mathrm{~A}$, the number of species $(S)$, information function $(H)$, equitability $(E)$ and Sanders' rarefied values of benthic foraminifera show significant fluctuations (figure 3). A comparison of these values with previous studies in the eastern and western Indian Ocean is more reasonable because we have used the $>125 \mu \mathrm{m}$ size fraction. The SHE and Sanders' rarefied values increase from 17.2 to 16.4 Ma coinciding with the late Early
Miocene Climatic Optimum (EMCO). The values decrease during 16.4 to 13 Ma when East Antarctic ice sheets (EAIS) underwent major expansion. All SHE parameters show a general increase with a fluctuating trend from $\sim 13$ to $11.6 \mathrm{Ma}$; thereafter the values show a decrease from 11.6 to $9 \mathrm{Ma}$ and then an increase with a peak at $7 \mathrm{Ma}$. The diversity values remain more or less constant since $7 \mathrm{Ma}$ with secular variations until the mid-Pleistocene transition (Raymo et al. 1997) when all the parameters showed an abrupt decrease at $\sim 1.2 \mathrm{Ma}$ (figure 3 ). There was no visible change in benthic faunal diversity at Hole 730A, western Arabian Sea during major expansion of the Northern Hemisphere Glaciation (NHG) in the late Pliocene (figure 3), although a major change has been observed in benthic fauna in the eastern Indian Ocean (Gupta and Thomas 2003). We relate this contrasting trend in benthic fauna and diversity to distinct water mass and climate regimes in the two regions. 


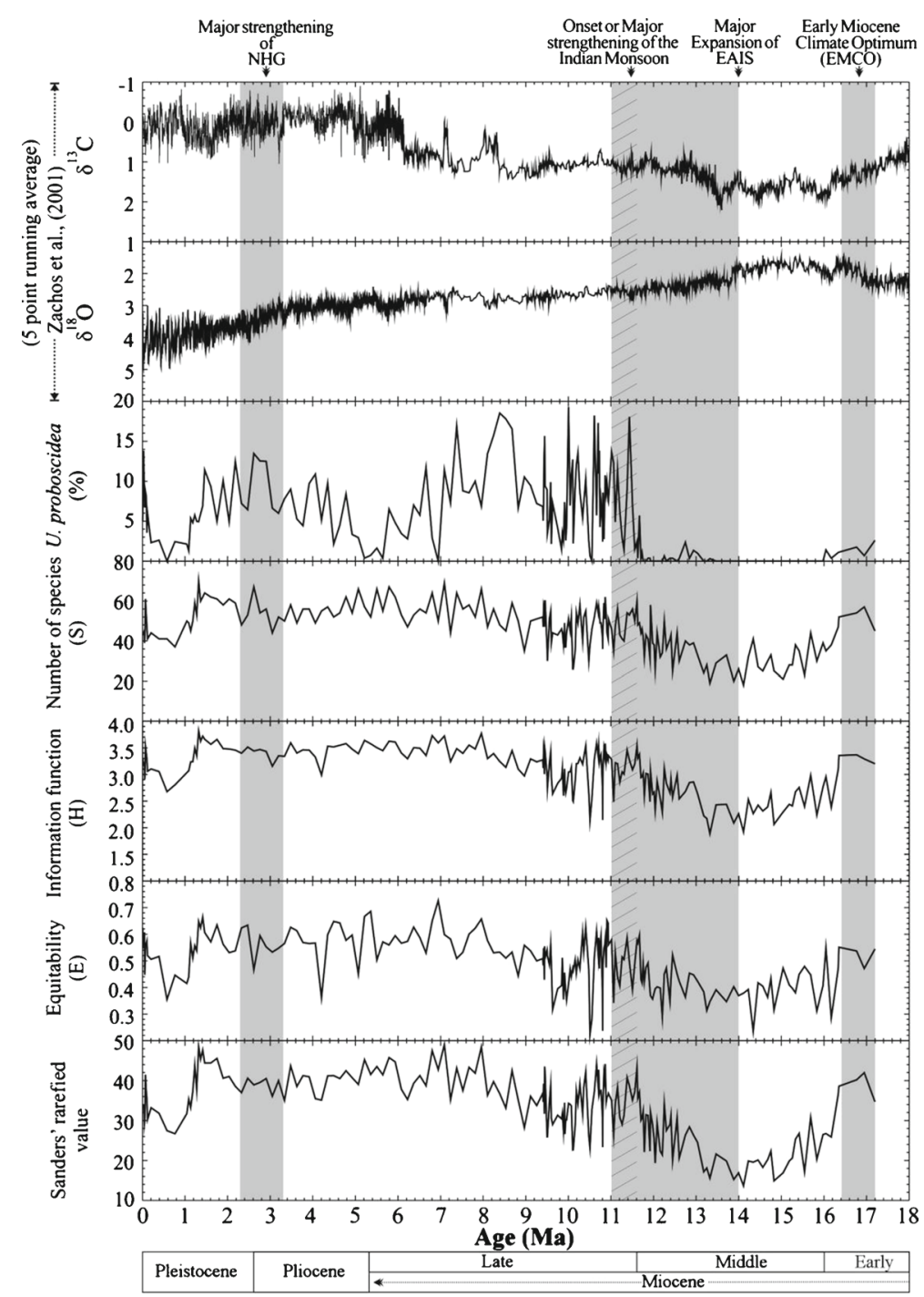

Figure 3. Species diversity parameters including $H, S, E$ and Sanders' rarefied values combined with Uvigerina proboscidea percentages at ODP Hole 730A. These values are correlated with global isotope curve (Zachos et al. 2001) to understand if changes in benthic foraminiferal populations at Hole $730 \mathrm{~A}$ were driven by global oceanic changes or Indian monsoon variability. The grey bars and hature lines coincide with Early Miocene Climate Optimum (EMCO), major expansion of East Antarctic Ice Sheets (EAIS), onset or beginning of Indian monsoon and major strengthening of Northern Hemisphere Glaciation (NHG).

Although, Sanders' values show a broad positive correlation $(R=0.50)$ with productivity indicator $U$. proboscidea during the entire studied interval, the relationship varies in different time segments (figure 4). For example, values of both the proxies show a strong negative correlation $(R=$ -0.86) during the late EMCO (17.2-16.4 Ma), but a strong positive correlation $(R=0.64)$ during 16.4-13 Ma coinciding with increased Antarctic ice volume (figure $4 \mathrm{~b}-\mathrm{c}$ ). The species diversity values were low in the latter interval as were earlier observed in the eastern Indian Ocean during this time (Gupta et al. 2013). The correlation breaks in the younger interval since $13 \mathrm{Ma}$ where $R$ values remain $<0.4$ in all the time slices (figure $4 \mathrm{~d}-\mathrm{f}$ ). We link this shift to greater influence of the Indian monsoon as this interval coincides with the onset of and increased seasonality in the Indian monsoon.

A sudden increase in Uvigerina proboscidea percentages at $11.6 \mathrm{Ma}$ at Hole $730 \mathrm{~A}$ appears to be linked to a significant increase in Indian monsoon intensity that drove increased upwelling and high surface productivity in the Arabian Sea. In the eastern Indian Ocean species, diversity values show a stepwise decrease since the early Miocene following major Antarctic ice volume increase with a rapid decrease in the late Miocene (Gupta et al. 2013). Thomas and Vincent (1987) also observed a decrease in diversity of deep-sea benthic foraminiferal faunas in the Pacific Ocean during this period. The species diversity values in the NW and eastern Indian Ocean show an opposite 

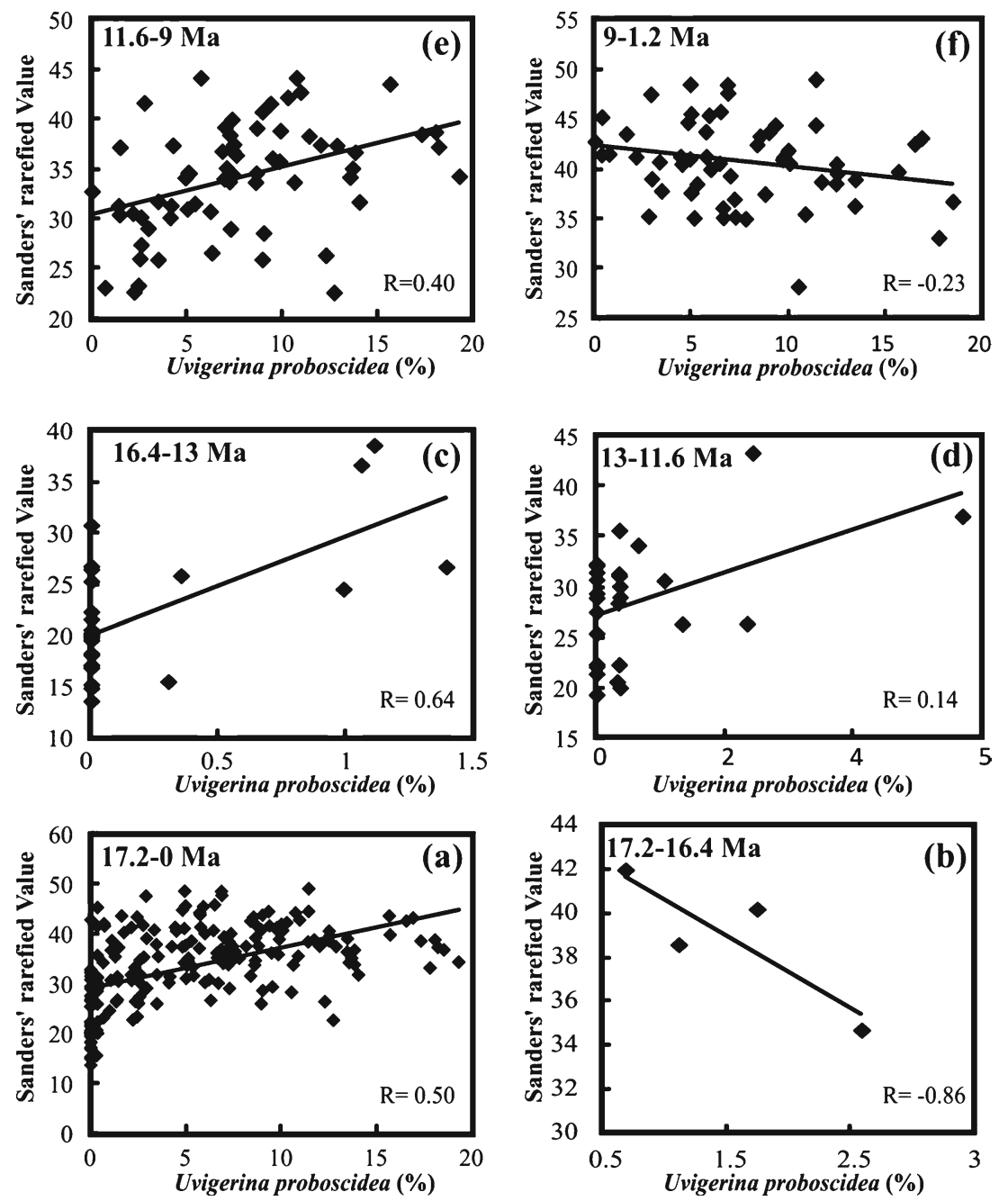

Figure 4. Linear correlation between Uvigerina proboscidea and Sanders' rarefied values over the past 17.2 Ma. The value of correlation coefficient $(R)$ is 0.5 for the whole 17.2 Ma period (a), -0.86 for the interval 17.2-16.4 Ma (b), 0.64 for 16.4-13 $\mathrm{Ma}(\mathbf{c}), 0.14$ for 13-11.6 Ma (d), 0.4 for 11.6-9 Ma (e), and -0.23 for 9-1.2 Ma interval (f).

trend indicating existence of contrasting climatic regimes in the two regions. The Arabian Sea was dominated by the monsoon regime since 13-12 Ma, whereas eastern Indian Ocean has been under the influence of the Southern Hemisphere climate and ocean circulation since the Oligocene.

The populations of Epistominella exigua and Cibicides wuellerstorfi increase coevally with Uvigerina proboscidea since $\sim 12 \mathrm{Ma}$ indicating increased monsoon seasonality resulting in highly variable upwelling in the western Arabian Sea. However, E. exigua almost disappears since $10 \mathrm{Ma}$ whereas OMZ species show major and sudden increase at $\sim 11 \mathrm{Ma}$ coinciding with increased intensity of the Indian monsoon (figure 2). These faunal trends at Hole 730A suggest strengthening of the Indian monsoon and OMZ since the middle Miocene. The increased abundances of Nuttallides umbonifera since ca $11 \mathrm{Ma}$ suggest presence of corrosive deep water in the Arabian Sea.
A major decrease in benthic diversity parameters across the mid-Pleistocene transition could be related to a cold phase during when the Indian monsoon was weaker. The present study suggests that changes in benthic foraminiferal populations and diversity at Hole $730 \mathrm{~A}$ were mainly driven by the Indian monsoon, and polar waters might have played a minor or no role since this hole has remained at this depth from the early Neogene period (Prell et al. 1989). The paleoposition of this hole has also remained the same since the Jurassic, thus making it ideal to study monsoon-induced changes in the western Arabian Sea.

\section{Conclusions}

Species diversity $(S, H, E$ and Sanders' rarefied values) values of benthic foraminifera at Hole $730 \mathrm{~A}$ combined with faunal abundances indicate 
monsoon wind-induced intense upwelling and thus high surface productivity since $\sim 12$ Ma suggesting the onset or major strengthening of the Indian monsoon and wind regimes. A correlation between diversity parameters and Uvigerina proboscidea abundances suggests that monsoon-induced productivity played a major role in shaping benthic foraminiferal diversity and abundances in the western Arabian Sea during the Miocene-Pleistocene. Furthermore, benthic foraminiferal trends do not show any significant correlation with global isotope shifts which predate changes at Hole 730A indicating that deep-sea changes in the western Arabian Sea were mainly driven by the Indian monsoon during the study interval. The polar deep waters may not have played a significant role in shaping benthic diversity at Hole 730A. Decrease in diversity parameters since the early Miocene were linked to low food levels as a result of a weak Indian monsoon.

\section{Acknowledgements}

A K G thanks Integrated Ocean Drilling Program (IODP) for providing samples for the present study (Req. No. 20204B) and Department of Science and Technology (DST), New Delhi for financial support (Grant No. SR/S4/ES-304/2007 and J.C. Bose Fellowship). A Y thanks DST, New Delhi (Grant No. SR/S4/ES-304/2007), Indian Institute of Technology, Kharagpur and Wadia Institute of Himalayan Geology (No.8/3/2013/2342) for financial and infrastructure support.

\section{References}

Almogi-Labin A, Schmiedl G, Hemleben C, Siman-Tov R, Segl M and Meischner D 2000 The influence of the NE winter monsoon on productivity changes in the Gulf of Aden, NW Arabian Sea, during the last 530 ka as recorded by foraminifera; Marine Micropaleontol. 40 295-319.

Barker P F and Thomas E 2004 Origin, signature and palaeoclimatic influence of the Antarctic Circumpolar Current; Earth-Sci. Rev. 66 143-162.

Berggren W A, Kent D V, Swisher C C and Aubry M-P 1995 A revised Cenozoic geochronology and chronostratigraphy; In: Geochronology, time scales, and global stratigraphic correlation, SEPM Spec. Publ. 54 129-212.

Boersma A and Mikkelsen N 1990 Miocene-age primary productivity episodes and oxygen minima in the central equatorial Indian Ocean; Sci. Results Proc. Ocean Drilling Program. 115 589-609.

Bremer M L and Lohmann G P 1982 Evidence for primary control of the distribution of certain Atlantic Ocean benthonic foraminifera by degree of carbonate saturation; Deep-Sea Res. 29 987-998.

Brock J C, McClain C R, Luther M E and Hay W W 1991 The phytoplankton bloom in the northwestern Arabian Sea during the southwest monsoon of $1979 ;$ J. Geophys. Res. Oceans 96 20,623-20,642.
Burke S C, Berger W H, Coulbourn W T and Vincent E 1993 Benthic foraminifera in Box Core ERDC 112, Ontong Java Plateau; J. Foram. Res. 23 19-39.

Buzas M A and Gibson T G 1969 Species diversity: Benthonic foraminifera in western North Atlantic; Science $16372-75$.

Corliss B H 1979 Recent deep-sea benthonic foraminiferal distributions in the southeast Indian Ocean: Inferred bottom water routes and ecological implications; Marine Geol. 31 115-138.

Corliss B H 1983 Distribution of Holocene deep-sea benthonic foraminifera in the southwest Indian Ocean; DeepSea Res. 30(2A) 95-117.

De S and Gupta A K 2010 Deep-sea faunal provinces and their inferred environments in the Indian Ocean based on distribution of Recent benthic foraminifera; Palaeogeol. Palaeoclimatol. Palaeoecol. 291 429-442.

Den Dulk M, Reichart G J, Van Heyst S, Zachariasse W and Van der Zwaan G 2000 Benthic foraminifera as proxies of organic matter flux and bottom water oxygenation? A case history from the northern Arabian Sea; Palaeogeol. Palaeoclimatol. Palaeoecol. 161 337-359.

Dickens G R and Owen R M 1999 The latest Mioceneearly Pliocene biogenic bloom: A revised Indian Ocean perspective; Marine Geol. 161 75-91.

Douglas R G and Woodruff F 1981 Deep sea benthic foraminifera; In: The Oceanic Lithosphere. The Sea (ed.) Emiliani E, Wiley-Interscience, New York, 7 1233-1327.

Ehrmann W U and Mackensen A 1992 Sedimentological evidence for the formation of an East Antarctic ice sheet in Eocene/Oligocene time; Palaeogeol. Palaeoclimatol. Palaeoecol. 93 85-112.

Findlater J 1971 Monthly mean airflow at low levels over the western Indian Ocean; Geophysical Memoirs 11553.

Gibson T G and Buzas M A 1973 Species diversity: Patterns in modern and Miocene foraminifera of the eastern margin of North America; Geol. Soc. Am. Bull. 84 217-238.

Glock N, Eisenhauer A, Milker Y, Liebetrau V, Schönfeld J, Mallon J, Sommer S and Hensen C 2011 Environmental influences on the pore density of Bolivina spissa (Cushman); J. Foram. Res. 41(1) 22-32.

Gooday A J 1993 Deep-sea benthic foraminiferal species, which exploit phytodetritus: Characteristic features and controls on distribution; Marine Micropaleontol. 22 $187-205$.

Gooday A J 1988 A response by benthic foraminifera to the deposition of phytodetritus in the deep sea; Nature 332 $70-73$.

Gupta A K 1994 Taxonomy and bathymetric distribution of Holocene deep-sea benthic foraminifera in the Indian Ocean and the Red Sea; Micropaleontol. 40(4) 351-367.

Gupta A K and Srinivasan M 1992 Uvigerina proboscidea abundances and paleoceanography of the northern Indian Ocean DSDP Site 214 during the Late Neogene; Marine Micropaleontol. 19 355-367.

Gupta A K and Thomas E 1999 Latest Miocene-Pleistocene productivity and deep-sea ventilation in the northwestern Indian Ocean (Deep Sea Drilling Project Site 219); Paleoceanography $\mathbf{1 4} 62-73$.

Gupta A K and Thomas E 2003 Initiation of Northern Hemisphere glaciation and strengthening of the northeast Indian monsoon: Ocean Drilling Program Site 758, eastern equatorial Indian Ocean; Geology 31 47-50.

Gupta A K, Joseph S and Thomas E 2001 Species diversity of Miocene deep-sea benthic foraminifera and watermass stratification in the northeastern Indian Ocean; Micropaleontol. 47 111-124.

Gupta A K, Singh R K, Joseph S and Thomas E 2004 Indian Ocean high-productivity event (10-8 Ma): Linked 
to global cooling or to the initiation of the Indian monsoons?; Geology 32753.

Gupta A K, Singh R K and Verma S 2013 Deep-sea palaeoceanographic evolution of the eastern Indian Ocean during the late Oligocene-Pleistocene: Species diversity trends in benthic foraminifera; Curr. Sci. 104 904-910.

Hamon N, Sepulchre P, Lefebvre V and Ramstein G 2013 The role of eastern Tethys seaway closure in the Middle Miocene Climatic Transition (ca. $14 \mathrm{Ma}$ ); Climate of the Past 9(6) 2687-2702.

Haug G H and Tiedemann R 1998 Effect of the formation of the Isthmus of Panama on Atlantic Ocean thermohaline circulation; Nature 393 673-676.

Hermelin J 1992 Variations in the benthic foraminiferal fauna of the Arabian Sea: A response to changes in upwelling intensity? Geol. Soc. London, Spec. Publ. 64 151-166.

Hermelin J and Shimmield G 1990 The importance of the oxygen minimum zone and sediment geochemistry in the distribution of Recent benthic foraminifera in the northwest Indian Ocean; Marine Geol. 91 1-29.

Hermoyian C S and Owen R M 2001 Late Miocene-early Pliocene biogenic bloom: Evidence from low-productivity regions of the Indian and Atlantic oceans; Paleoceanography 16 95-100.

Jannink N, Zachariasse W and Van der Zwaan G 1998 Living (Rose Bengal stained) benthic foraminifera from the Pakistan continental margin (northern Arabian Sea); Deep-Sea Res. Part I 45 1483-1513.

Kawagata S, Hayward B W and Gupta A K 2006 Benthic foraminiferal extinctions linked to late PliocenePleistocene deep-sea circulation changes in the northern Indian Ocean (ODP Sites 722 and 758); Marine Micropaleontol. 58 219-242.

Kennett J P and Barker P F 1990 Latest Cretaceous to Cenozoic climate and oceanographic developments in the Weddell Sea, Antarctica: An ocean-drilling perspective; In: Proceedings of the Ocean Drilling Program, Scientific Results 113 937-960.

Kennett J, Houtz R, Andrews P, Edwards A, Gostin V, Hajos M, Hampton M, Jenkins D, Margolis S and Ovenshine A 1974 Development of the circum-Antarctic current; Science 186 144-147.

Kroon D, Steens T N F and Troelstra S R 1991 Onset of monsoonal related upwelling in the western Arabian Sea as revealed by planktonic foraminifers; In: Proceeding Ocean Drilling Program, Scientific Results 117 257-263.

Kurbjeweit F, Schmiedl G, Schiebel R, Hemleben C, Pfannkuche O, Wallmann K and Schäfer P 2000 Distribution, biomass and diversity of benthic foraminifera in relation to sediment geochemistry in the Arabian Sea; Deep-Sea Res. Part II: Topical Studies in Oceanography $472913-2955$.

Lawver L A and Gahagan L M 1998 Opening of drake passage and its impact on Cenozoic ocean circulation; Oxford Monogr. Geol. Geophys. 39 212-226.

Linke P and Lutze G F 1993 Microhabitat preferences of benthic foraminifera - a static concept or a dynamic adaption to optimize food acquisition?; Marine Micropaleontol. 20 215-234.

Lutze G F and Thiel H 1989 Epibenthic foraminifera from elevated microhabitats: Cibicidoides wuellerstorfi and Planulina ariminensis; J. Foram. Res. 19 153-158.

Mackensen A, Schmiedl G, Harloff J and Giese M 1995 Deepsea foraminifera in the South Atlantic Ocean: Ecology and assemblage generation; Micropaleontol. 41 342-358.

Mazumder A, Henriques P J and Nigam R 2003 Distribution of benthic foraminifera within oxygen minima zone, off central west coast, India; Gondwana Geol. Mag. 6 5-10.
Miao Q and Thunell R C 1993 Recent deep-sea benthic foraminiferal distributions in the South China and Sulu Seas; Marine Micropaleontol. 22(1) 1-32.

Molnar P, England P and Martinod J 1993 Mantle dynamics, uplift of the Tibetan Plateau, and the Indian monsoon; Rev. Geophys. 31(4) 357-396.

Nigam R, Mazumder A, Henriques P J and Saraswat R 2007 Benthic foraminifera as proxy for oxygen-depleted conditions off the central west coast of India; J. Geol. Soc. India 70 1047-1054.

Pisias N G, Mayer L A and Mix A C 1995 Paleoceanography of the eastern equatorial Pacific during the Neogene; Synthesis of Leg 138 drilling results.

Prell W L and Niitsuma N et al. 1989 Proc. ODP, Initial Reports: College Station, TX (Ocean Drilling Program) 117.

Prell W L, Murray D W, Clemens S C and Anderson D M 1992 Evolution and variability of the Indian Ocean summer monsoon: Evidence from the western Arabian Sea drilling program; Geophys. Monogr. Series 70 447-469.

Rai A and Singh V 2001 Late Neogene deep-sea benthic foraminifera at ODP Site 762B, eastern Indian Ocean: Diversity trends and palaeoceanography; Palaeogeol. Palaeoclimatol. Palaeoecol. 173 1-8.

Raymo M E, Oppo D W and Curry W 1997 The midPleistocene climate transition: A deep sea carbon isotopic perspective; Paleoceanogr. 12 546-559.

Reid J L 2003 On the total geostrophic circulation of the Indian Ocean: Flow patterns, tracers, and transports; Progr. Oceanogr. 56 137-186.

Rex M A, Etter R and Stuart C T 1997 Large-scale patterns of species diversity in the deep-sea benthos; In: Marine biodiversity: Patterns and processes, Cambridge University Press, Cambridge, pp. 94-121.

Sanders H L 1968 Marine benthic diversity: A comparative study; American Naturalist. 102 243-282.

Saraswat R, Nigam R and Barreto L 2005 Palaeoceanographic implications of abundance and mean proloculus diameter of benthic foraminiferal species Epistominella exigua in subsurface sediments from distal Bay of Bengal fan; J. Earth Syst. Sci. 114(5) 453-458.

Schmiedl G, Mackensen A and Muller P J 1997 Recent benthic foraminifera from the eastern South Atlantic Ocean: Dependence on food supply and water masses; Marine Micropaleontol. 32 249-287.

Schott F A and McCreary J P 2001 The monsoon circulation of the Indian Ocean; Progr. Oceanogr. 51 1-123.

Sen Gupta B K and Bernhard J M 1999 Foraminifera in oxygen-depleted environments; In: Modern Foraminifera (ed.) Sen Gupta B K (The Netherlands: Kluwer Academic Publishers) 371 201-206.

Shannon C E and Wiener W 1949 The mathematical theory of communication; Urbana, Univ. Illinois Press 111 $1-125$.

Singh R K and Gupta A K 2004 Late Oligocene-Miocene paleoceanographic evolution of the southeastern Indian Ocean: Evidence from deep-sea benthic foraminifera (ODP Site 757); Marine Micropaleontol. 51 153170.

Singh R K, Gupta A K and Das M 2012 Paleoceanographic significance of deep-sea benthic foraminiferal species diversity at southeastern Indian Ocean Hole 752A during the Neogene; Palaeogeol. Palaeoclimatol. Palaeoecol. 361-362 94-103.

Smart C W, King S C, Gooday A J, Murray J W and Thomas E 1994 A benthic foraminiferal proxy of pulsed organic mater paleofluxes; Marine Micropaleontol. 23 89-99. 
Smart C W, Thomas E and Ramsay A T S 2007 Middlelate Miocene benthic foraminifera in a western equatorial Indian Ocean depth transect: Paleoceanographic implications; Palaeogeol. Palaeoclimatol. Palaeoecol. 247 402-420.

Tchernia P 1980 Descriptive regional oceanography; Oxford: Pergamon Press, 253p.

Thomas E and Vincent E 1987 Equatorial Pacific deep-sea benthic foraminifera: Faunal changes before the middle Miocene polar cooling; Geology 15 1035-1039.

Tomczak M and Godfrey J S 1994 Regional Oceanography: An Introduction; Pergamon, New York.

Vincent E, Frerichs W and Heiman M 1974 Neogene planktonic foraminifera from the Gulf of Aden and the western tropical Indian Ocean, Deep Sea Drilling Project, Leg 24; Initial Reports of the Deep Sea Drilling Project 24 827-849.
Woelk S and Quadfasel D 1996 Renewal of deep water in the Red Sea during 1982-1987; J. Geophys. Res.: Oceans 101 18,155-18,165.

Wyrtki K 1971 Oceanographic Atlas of the International Indian Ocean Expedition; National Science Foundation, Washington DC, 531p.

Wyrtki K 1973 Physical oceanography of the Indian Ocean; In: The Biology of the Indian Ocean, Springer, pp. 18-36.

Wyrtki K 1988 Oceanographic atlas of the international Indian Ocean expedition.

You Y 1998 Intermediate water circulation and ventilation of the Indian Ocean derived from water-mass contributions; J. Marine Res. 56 1029-1067.

Zachos J, Pagani M, Sloan L, Thomas E and Billups K 2001 Trends, rhythms, and aberrations in global climate $65 \mathrm{Ma}$ to present; Science 292 686-693.

MS received 8 December 2013; revised 16 June 2014; accepted 18 June 2014 